The Sri Lanka Journal of the Humanities (2017) 41: 1\&2, 46-63

DOI: http://doi.org/10.4038/sljh.v41i1-2.7244

Published online: 15 March 2018

(C) University of Peradeniya

\title{
The Influence of Indian Culture, Arts, and Aesthetics on the Work of George Keyt
}

\author{
W.M.P. SUDARSHANA BANDARA ${ }^{1}$ \\ ${ }^{1}$ Department of Fine Arts, University of Peradeniya, Sri Lanka \\ ${ }^{1}$ sudabandara@gmail.com
}

\begin{abstract}
George Perceivel Keyt (1901-1993) who belonged to the '43 Group of Sri Lankan Artists was one of the most gifted, distinguished, and universal of contemporary Sri Lankan painters of the 20th Century, well known both in the East and the West. His work consists of over 12,000 paintings and sketches. This study examines the personal record of George Keyt and the socio cultural context of his painting career in order to identify his exposure to the Indian culture and aesthetics. This study further explores Bharatamuni's rasa concept as an aesthetic concept and a theoretical basis that could accommodate all his paintings, at the levels of analysis and appreciation. Finally, it elaborates the influence of Indian culture, art, and aesthetic concepts, especially the rasa concept, as reflected in the works of George Keyt and concludes with evidence that the rasa concept could be used as a
\end{abstract}


theoretical basis in analyzing his work. So far, art critics, historians and archeologists, such as Sunil Goonasekera, Nihal Rodrigo, Navil Weerarathna, Senaka Bandaranayake, and Martin Russell, have primarily discussed the influence of modern western art forms on the works of George Keyt. While acknowledging such influence on Keyt's work, this study explores the extent to which the Indian culture, art, and aesthetic concepts have shaped his paintings. The study also formulates a theoretical basis that explains Keyt's approach to art.

Keywords: rasa concept, aesthetics, '43 Group, Indian culture

\section{George Keyt's Life, Career, and Socio-cultural Context}

"True painting is not description, as there is another language for that. It is not even definition. Its emphasis is in its most unequivocal form of line, colour and shape. But to those not literate in it, painting is as meaningless as any other foreign language, though perhaps more tantalising” (Halpe 81). Keyt made this statement in 1946 in Bombay, India, responding to the critics and friends who found "modern art" to be complicated. This statement explains why many cannot comprehend what modern art is. Keyt, as a member of the ' 43 Group, was well recognized and appreciated by both local and international art critics. Being a professional artist, he held many local and international exhibitions and managed to mark his local identity through his work (Anand 17).

George Percival Sproule Keyt was born on April 17, 1901, in Kandy. Born into a middle class Burgher family, he was brought up in a pro-western social environment that cherished western values and accepted British imperialism. Educated at Trinity College, Kandy, he was further exposed to western cultural milieu. 
However, he was not interested in studies; his interests were focused on reading and painting. He learnt local culture and Buddhism as well (Goonetileke, "A Biographical Sketch" 21-29).

Keyt lived close to the Malwaththa Temple, and his association with that Temple had a substantial impact on his life. Through his association with the Temple from his childhood, Keyt learnt Buddhism which affected his attitudes and spirit. He started wearing the "Arya Sinhala" outfit in place of the western dress, which he had formerly worn, started using a Palmyra fan as essential equipment in his day-to-day life, associated himself with ordinary village folk, started learning and practicing village customs, and wrote many articles on the value of Buddhist philosophy. He learnt the Sinhala and Sanskrit languages from Rev. Pinnawela Dheerananda (Goonasekara 1-5). As a result, he could, in 1940, translate the Sanskrit text Gitagovinda by the Twelfth-Century poet Jayadeva, into English (Rodrigo 51-57). He included his own line-drawings in this translation to illustrate certain events of this poetic text. Those line-drawings portray the grammar of his art in its early form. He translated some Sinhala Buddhist texts into English, such as Buddhism and Ethics, Jayamaingala Gāthā, and A Tale of Old Ceylon, with the aim of supporting the Buddhist revival movement of the 1920s (Rodrigo 51-57).

By 1926, Keyt had completed a significant portion of his painting career under the guidance of Lionel Wendt. Keyt, who had not learnt art in an institutional setting, improved his knowledge by referring to books and paintings of many local and international artists. He was a poet, a translator, and a great painter who studied art on his own. He was able to become a member of the ' 43 Group pioneered by Lionel Wendt. He collaborated with his contemporary artists, such as Geoffrey Beling, George Claessen, Aubrey Collette, Justin Pieris Deraniyagala, and Ivan Pieris, in 
order to hold exhibitions. Keyt's encounter with Wendt paved the way for his first exhibition with Geoffrey Beling and a meeting with C. F. Winzer and Martin Russel (Archer 22).

He married Ruth Jansz in 1930. They had two girls-Diana and Flavia. After a decade of a rather unsatisfactory marital relationship, Ruth left the country with their two daughters. Ruth's departure was followed by another special event-Keyt's second marriage to Pilawela Menike-in 1943. He lived with her in a rural village in Kandy and had two sons from her-Prem and Sachin. While holding an exhibition in Bombay, India, in 1953, Keyt met Kusum and started living together with her.

\section{Influences of Indian Culture, Visual Arts, and Aesthetics}

Keyt selected his subjects from Hindu myths and Buddhist themes. Due to the influence of the local culture, he developed an interest in Buddhism and Hinduism in his childhood itself. His interests in Buddhism, Hinduism, and Indian culture directed him towards Indian visual arts, such as sculpture and painting, and led him to borrow ideas from Indian aesthetic theories, specifically from Bharatamuni's concept of rasa. He had connections with many renowned Indian artists, and he was a fan and friend of Tagore. He closely followed Tagore at certain times (Russell, "Introduction and Biographical Note" 67). Keyt was interested in Hindu mythology, and stories such as Śiva-Pārvatī fascinated him. His inclination towards Hinduism can be seen as an important aspect of his life. He painted the sculptures that he had seen at the Hindu Temples of Khajuraho, Bhuvanesvar, and Konarak. Keyt was undoubtedly influenced by those sculptures and carvings (Goonetileke, "The Indian Ethos" 53-59).

Keyt got an opportunity to visit India with his sister Peggy Keyt and her husband Harold Peiris in 1939 (Russell, "Introduction and 
Biographical Note" 51). They visited the Great Temple at Madura, the Sri Rangam Temple, and the Chidambaram Temple, which are related to the mythology surrounding Siva. While in Bangalore, Keyt renewed his acquaintance with G. Venkatachalam, who had supported him ten years ago, during a controversy over Keyt's 1930 exhibition, and Venkatachalam introduced him to Shanta, the famous South Indian dancer. During his trip, Keyt also visited the birthplace of Śankarācārya and the Golden Rock at Trichinopoly.

Keyt was interested in Buddhist Tantric concepts as well as romantic, erotic concepts, and those interests found expression through his work, particularly those created during the 1938-1947 period. His use of flat colours and rapid rhythmic lines was a defining feature of his art during this period. His works titled Maithuna, Jhula, Sivasoka, and Draupadi best exemplify his approach to art during this period (Goonasekera 58, 59, 73, 71). The themes of these works were derived from Indian mythology, and Keyt presented them in an objective perspective. The symbolic and connotative meaning that he gave expression to through his works made his works emerge as important works of art.

Some of Keyt's works emphasize female nudity, a feature that adds symbolic meaning to the relevant thematic depictions. The eastern concept of the vine-like female figure was widely used by Keyt during this period. His works such as Rati (Goonasekera 61), Sringara Rasa (Russell, "Introduction and Biographical Note" Plate 42), Thilottima, The Rehearsal (Rodrigo 53), Lovers, and Mohini could be cited as cases in point. Female nudity as depicted in these paintings communicates several rasa concepts, particularly the Śrngāra rasa. The Rati represents the Indian mythical story of Rama and Sita. Rama who is clad in white, bearing a white lotus in his hand, represents chastity and 
spirituality. Sita with full breasts and half-closed eyes, barechested, clad in a red lower garment, is twined around Rama like a vine. Through the collision of two contradictory qualities represented by the two figures, Keyt highlighted the erotic aspect of the painting. The painting The Rehearsal portrays a nude female dancer. The eyes of the musicians in the painting are directed at the woman's thighs and genitals. Keyt created many paintings under the title "Lovers". Of them, the one he created in 1975 is subjected to wide analysis. The painting depicts a man and a woman in a tight embrace. The roughness of the male is evoked through his dark-brown body, while the gracefulness of the female is highlighted by her light-brown shade, slim waist, and narrow hips. The black and red in the background emphasise the erotic nature of the embrace.

Keyt was specifically influenced by the sculptures and carvings of Khajuraho, Bhuvaneshvar, and Konarak, which belong to the Tantric Buddhist tradition (Jayawardena 38). This influence is visible in his works during 1940-1970 for which the subject was derived from Hindu mythology: Woman with Buffalo (Goonetileke, "The Indian Ethos" 48), Mahesh Mardini (Dissanayake 42), Ganesha and Vigneshvari, Radha and Krishna (Candappa 101), Tilottima, Krishna Painting Radha, Balakrishna, and Markendeya (Russell, "Introduction and Biographical Note" 71). Keyt gave expression to the characters and events from Hindu mythology, emphasizing the universal nature of that mythology and related concepts. For instance, in the Radha and Krishna, he depicts the universality of love. Radha exemplifies the innate female grace, rhythm, and eroticism, while Krishna is depicted as the embodiment of male strength, toughness, and personality. His paintings that carry Hindu themes are rather erotic.

In places like Khajuraho and Bhubaneshvar, the sculptures mainly depict intimate human behaviour. There is no doubt that 
Keyt's erotic paintings were influenced by them. The nude female figures in his paintings, such as Gopika Vastra Paharaha (Candappa 88), Entering the Dance (Candappa 105), Mohini, Sri Kalyani Murti, and Krishna Painting Radha bear a strong resemblance to the sculptures found at these places. The round face, the thin waist, the full breasts, the wide hips, and the curved knees and hips of the female sculptures are some of the defining features of these paintings.

The sculptures at Khajuraho and Bhuvaneshvar are considered remarkable works of art even today, and it is clear that Keyt had closely followed the style of those sculptures. For instance, the Mahesh Mardini (Goonasekera 114) is an imitation of Durga Killing the Buffalo (Goonasekera 115). The subject of the painting is a woman killing a buffalo. In the sculpture, she stabs the bull with a weapon. In the Mahesh Mardini, Keyt portrays a similar event but this time with the addition of some geometrical shapes to the bull figure. Rapid, short lines depict the conflict-ridden, aggressive nature of the event. The bull is suppressed by the woman, and there can be many interpretations to this depiction. Moreover, Keyt painted the Ganesha and Vigneshvari (Goonasekera 117) adapting the bar-relief sculpture Ganesha and Sakti of Khajuraho.

Keyt's art was also influenced by the sketches found in the books written about the Jain culture. One such important sketch is the Consecration of Mahavira. The bare-chested woman in this picture, who has a traight look in her eyes and holds her hair with her right hand, resembles the female figure in Keyt's Girl with Mirror. The facial expressions, postures, popping eyes, body rhythm, and the direct gaze of the two female figures are almost the same (Russell, "George Keyt" 68). 
The archeological findings in Sri Lanka prove that Sri Lankan sculpture boasts a long history. Among the ancient sculptures found in the country, the bronze sculptures of the Polonnaruwa period are outstanding, and they bear influence of certain South Indian sculpture traditions. There are many instances that suggest that Keyt was also influenced by this art form. The Goddess Tara (Lohuizen-De Leeuw 25) at the Museum of Britain, the Standing Parvathi (Schroeder 114) at the Metropolitan Museum of Art, the Sivakumara Sundara (Schroeder 120) at the Polonnaruwa Museum, and the Devi (Goonasekera 103) are among the prominent sculptures that influenced Keyt. The sculptures that belong to the $14^{\text {th }}$ or $15^{\text {th }}$ Century $\mathrm{AD}$, which are available in the Philadelphia Museum, which Keyt had a chance to visit (Russell, "George Keyt" 32) are similar to the images in Keyt's paintings; for instance, the female figure in the Artist with Model (1957) (Goonasekera 100) is quite similar to the female figures in the above-mentioned sculptures. The slim waist and hands, full breasts, wide hips, dancing posture, long face, and pointed nose of those sculptures could be found in Keyt's paintings as well.

It is clear that Keyt tried to use his knowledge of Indian art, culture, and aesthetics in his work. The works that he created during the period 1936-1943, such as Maithunna (1936), Jhula (1936), Rati (1936), Draupadi (1936), Sivasoka (1938), Devdasi (1936), Sringara Rasa (1936), The Lord's Departure (1936), Sri Krishna and the Gopis (1936), Varsha Vihara (1936), and Vibhatsa Rasa (1938), could be cited as examples (Russell, "George Keyt" 17). According to Martin Russel, Sunil Gunesekara, and Laxmi P. Sihare, Keyt's art during this period was based on the idea of love (Sihare 48). In his works, he tried to capture heavenly love between heavenly lovers such as Krishna and Gopika, as opposed to love between human lovers (Goonasekera 55). 
As mentioned above, the Sringara Rasa, Krishna and Gopis, Varsha Vihara, Jhula, Rati, and Maithunna, which were created in 1936, depict the idea of eroticism connected to the idea of love. It could be observed that Keyt frequently used themes, such as erotic love and grief in his works, and this arguably reflects his familiarity with Bharatamuni's aesthetic concept of rasa (taste). A detailed investigation of this aesthetic concept would be useful in analyzing Keyt's woks in detail.

\section{Bharatamuni's Rasa Concept}

The Nâtyaśāstra, which is considered to have been written by Bharatamuni in the $7^{\text {th }}$ or $8^{\text {th }}$ Century A.D., is primarily about Sanskrit drama and its functions (Rangacharya xvii). Yet, the idea has been used in analysing and appreciating other works of art, for example, literature and visual arts. Bharatamuni described rasa as "whatever is enjoyed by the senses" (Rangacharya 53). The simple meaning of this statement, one could argue, is the sensual pleasure that is derived when enjoying something.

In the chapter "Drama Field" (Chapter 6), it is said, "Emotions in poetry come to be expressed through the conjunctions of their causes and symptoms and other ancillary feelings that accompany the emotions" (Rangacharya 55). The concept of rasa denotes the outcome of the combination of causal emotions, symptomatic emotions, and other ancillary feelings that accompany those emotions. According to Bharatamuni, in addition to these three type of sentiments, there is another type of sentiments called stable sentiments. Even though he has not mentioned stable sentiments in the rasasūtra, he has described it in a later chapter:

By the manner in which taste or appetite is created by the combination of various condiments, edible plants etc., and 
by the manner in which taste could be produced by the combination of pure sugar, condiments and vegetables, so can 'rasa' state happen with the combination of stable sentiments, causal emotions, symptomatic emotions and other ancillary feelings that accompany the emotions. (Rangacharya 46)

Rasa is the cumulative result of vibhāva (stimulus), anubhāva (involuntary reaction), and vyabhicāribhāva (voluntary reaction) [Rangacharya 55]. This shows how Bharatamuni has explained the rasa concept with the help of the simple example of bhâva in his analysis. Furthermore, in his analysis, Bharatamuni provides an uncomplicated explanation as to how rasa should be experienced. He says, "As a person with an appetite enjoys and derives happiness by consuming a meal which is prepared with various condiments, so will the viewers with a formulated mind derive enjoyment and happiness by seeing and hearing the mimes, words and involuntary reactions" (Rangacharya 59).

According to Bharatamuni there are inherent, inborn, and unseen sentiments or emotions within human beings, and they are called stable sentiments. He further explains that these stable sentiments are nourished by causal emotions, symptomatic emotions, and other ancillary feelings which the combination of which results in the generation of rasa. Out of a total of forty-nine (49) stable sentiments, he has mentioned eight sentiments in his Nātyaśâstra: erotic love, comic laughter, grief, rage, the heroic, fear, disgust, wonder (Rangacharya 53-63). According to him, these eight sentiments are prominent compared to the rest. According to Bharatamuni, the eight basic rasa derived from these stable sentiments are as follows: Śrngāra (the 'erotic rasa' created by the stable sentiment of erotic love); Hâsya (the 'comic laughter rasa' created by the stable sentiment of comic laughter); Karuna (the 'grief rasa' created by the stable sentiment of grief); Raudra 
(the 'rage rasa' created by the stable sentiment of rage); Vìra (the 'heroic rasa' created by the stable sentiment of the heroic); Bhayānkara (the 'fear rasa' created by the stable sentiment of fear); Bībhatsa (the 'disgust rasa' created by the stable sentiment of disgust); and Adbhüta (the 'wonder rasa' created by the stable sentiment of wonder) [Rangacharya 54].

At the same time, it is important to get an understanding of the three sentiments explained by Bharatamuni. Causal emotions are the causes that enliven an emotion. This takes place in two ways, involving sentiments of two streams, namely humanitarian sentiments and environmental sentiments. They could also be called emotions of intentional objects and emotions of exciting causes respectively. The emotions of intentional objects or humanitarian sentiments are the objects that generate a certain delight. For example, an emotion of intentional objects, possessing the stable sentiment of erotic love, is the emotion of a lover. The emotions of exciting causes or environmental sentiments are the environmental factors which increases one's inclination towards love. Moonlight, summer, a cold night, the mild breeze, and the fragrance of flowers could be cited as examples.

According to Bharatamuni's description, a symptom is a transmission of different sentiments, which are aroused by the causal emotions in the audience through the use of certain physical attributes and gestures. For example, a person would express the sentiment of grief to the audience by crying, lamenting, or through any other expression of sadness. Clothes, colours, and facial expressions are among the attributes that are used to this end in the visual arts (Rangacharya 54-58).

The description about the ancillary feelings that accompany the emotions in Bharatamuni's Nātyaśāstra is not very clear (Marasinghe 12). Ancillary feelings are the other minor and 
impermanent sentiments that assist the major sentiments in the generation of rasa. When these act simultaneously with the stable sentiments, they are, most of the time, called moments of imagination. Bharatamuni has introduced thirty-three such sentiments, which includes states like disappointment, weakness, and suspicion (Rangacharya 54-55). The hallmark of these ancillary feelings is that they emerge in different moments and get combined with the main sentiments.

\section{Rasa Concept as Applied to Keyt's Works}

As pointed out earlier, George Keyt appears to have used Bharatamuni's rasa concept for his creations, especially for his works after 1936, where he increasingly used Hindu myths. For instance, the works such as Rati, Jhula, Maithuna, and Sringara Rasa, which are related to myths from Sanskrit literature, give expression to the concept of rasa. One could derive the intended enjoyment of his works by analyzing them from the point of view of rasa.

An analysis of the Rati, a work of art that George Keyt created in 1936 (Goonasekera 61), from the point of view of the rasa theory would be as follows. The objects of this drawing are the two main characters in the Rāmāyaṇa: Rāma and Sītā. The painting depicts them in an embrace. Keyt has used a rhythmic pattern and lighter spectrum of colours in this painting. Rāma is dressed in white and has a white lotus flower in his left hand, a bow in his right hand, and a case of arrows is seen hanging on his back. Sìtā is portrayed in a sensual manner. She is leaning against Rāma who is seated; one of her arms is around his head, while the other hand is stroking her own hair. Sìtā's upper body is full-breasted and nude. There is a red cloth around the lower part of her body. The halfclosed eyes, the full breasts, and the nymph-like body highlight 
the idea of erotic love. A simple spectrum of colours has been used to fill the background of the painting.

According to the rasa concept, the inborn stable sentiment called eroticism is the main cause of erotic love, and the Rati depicts that form of love. There are two causal emotions associated with this work, and they are the emotions of intentional objects and the emotions of exciting causes. The emotions of intentional objects or humanitarian sentiments are the factors that are best suited to generating rasa. The idea of love, particularly erotic love, is depicted through the image of Sītā. Sìtā is half-naked and fullbreasted and is leaning against Rāma's body. Even though the artist has not paid much attention to the environmental factors which arouse emotions, he has made an effort to portray an environment of solitude. Such an environment is best suited to foregrounding the idea of erotic love. Had the artist made an effort to portray the features of a complicated environment the causal emotions expressed through the form of Sìtā would not have been prominent.

Keyt has given expression to certain symptomatic emotions and ancillary feelings through this creation. He has used colours, lines, shapes, and the placement of forms with that objective in mind. Sìtā's body is in reddish-brown, with the lower part covered with a red cloth. The artist has made an effort to highlight the idea of erotic love in his depiction of Sìtā. In an effort to portray the peacefulness and desire-less nature of Rāma, defined by the absence of erotic love, the artist has drawn Rāma in white attire, with a white lotus in one hand and a bow in the other. According to Bharatamuni, ancillary feelings arise and cease within stable sentiments. In this work of art, ancillary feelings are expressed by Sìtā's half-closed eyes, the beauty of her body, the way she embraces Rāma with her right arm, the eye-to-eye gaze of the two, and the close proximity of the two figures. 
Keyt has shown a tendency to create works of art in a manner that they give expression to different sentiments associated with the rasa concept. There are instances where he has combined different types of rasa within the same creation with the intention of generating different meanings. Keyt creates a sense of curiosity within the viewer by depicting both the rasa of erotic love and the rasa of peacefulness within the Rati, for instance.

It is a challenging task to present certain emotions and feelings associated with the concept of rasa-ancillary feelings for instance-due to the difficulties involved in representing action in motion. Yet, through the skillful use of artistic techniques those challenges could be overcome. In the Jhula (1936), Keyt tries to give expression to erotic love between two lovers (Goonasekera 60). He uses the image of a swing that is in motion in order to introduce a sense of movement. Even though there is a thin cloth covering the upper body of the woman who is on the swing, she becomes naked due to the movement of the swing. She is depicted in a close embrace with the man on the swing. The rhythmic and free lines within the painting, which portray the freedom of the two lovers and the movement of the swing, are the defining features of the painting. These lines are a powerful means by which the close bond between the man and the woman is portrayed. The painting has a woman, who is watching the incident covertly, on the left side of the artwork. Who is this woman in hiding? Why is she covertly watching the scenario of love between the lovers? What is her connection to these lovers? These questions do not have definite answers. However, it appears that through this female figure, Keyt has tried to arouse various sentiments within the viewer.

Another special feature that should be noted is his tendency to highlight female nudity. Keyt presents the rhythm and the erotic love associated with the female figure appreciatively and without 
limitations. The paintings titled Sri Krishna and the Gopis, The Lord's Departure, and Sringara Rasa could be cited as cases in point. It is the opinion of many critics that the rhythmic lines used by Keyt successfully convey the beauty, the rhythm, and the erotic love associated with a woman's body. Other special features of his paintings include the use of symbolic colours and the free combination of colours within the painting. However, the most prominent feature of his artworks produced during this period is the influence of the Indian literature and arts.

Keyt who depicted beauty, peacefulness, and eroticism in his early works used Sri Krishna as a model to depict violence, emptiness, and destruction in some of his drawings in 1938. He produced many works using the image of the great destroyer Siva. The subject of his drawings during this time was the mighty Siva and his dominance (Russell, "Introduction and Biographical Note" 51). The artworks that Keyt produced in 1938 include the Vibhatsa Rasa (depicting the dancing of and the destruction caused by the ferocious God Śiva), the Mahesvara (depicting a violent Siva riding fast on an ox, which is his vehicle), and the Yama and Savitri (depicting the vicious look of King Yama at naked Sāvitri).

Śiva is in a violent mood in the Bībhatsa Rasa and the Maheśvara. The special feature of these two works is the depiction of a naked and violent Śiva. Furthermore, in the Rakshas Vivahaya (1938), he depicts a woman who is being held against her will. It portrays a man who embraces a woman who tries hard to free herself. These paintings reveal the way he used the rasa concept to illustrate his own emotions, while incorporating into them certain aspects of the Indian cultural tradition. In the series of artworks called Jalaja during the same year, Keyt portrayed a dancer called Jalaja in a disillusioned dancing posture. The colours and style, which he used in this series of paintings, helped him convey the intended emotions in a successful manner. He depicted the mental 
struggle within himself in a powerful manner by using lines and the colour white frequently. White symbolizes disillusionment and solitude, while the complicated lines all over the drawing symbolize his mental struggle. He deviated from the violent dancing style of Śiva and portrayed his disappointment and hopelessness through a mediocre dancing style, which could be understood in relation to the concept of rasa.

Accordingly, it is clear that Bharatamuni's rasa concept defines the works that Keyt created in 1937 and 1938. The different works of art that he created give expression to different types of rasa. The translation of Jayadeva's Gittagovinda (1940), which is a Hindu love epic, carries a number of sketches by Kyte which illustrate the story. These sketches also exhibit the influence of Indian art in Keyt's paintings. The full female figures of these sketches evoke erotic feelings, with their full breasts, slim waists, strong hips, arms, limbs, dhoti, and poona code around their waist. Thus, these sketches too can be considered a fine example of his remarkable ability to incorporate the rasa concept into his works.

\section{Conclusion}

George Keyt initiated a distinctly Sri Lankan art form characterized by the influence of many cultures and art forms. His paintings show the influence of many different art traditions, and the Indian art tradition could be recognized as the most influential among them. Bharatamuni's aesthetic concept of rasa seems to have had profound impact on his works. That concept is so central to his works that it could even be used as a theoretical basis for analyzing his works. 


\section{Works Cited}

Anand, Mulk Raj. "Conversations." George Keyt: A Centennial Anthology, edited by Reggie Candappa, Cedric de Silva, Sita de Silva, Arun Dias Bandaranaike, and Manilal Weerakoon, Colombo, George Keyt Foundation, 2001, pp. 15-20.

Archer, W.G. "The Early Phase.” George Keyt: A Felicitation Volume, edited by George Keyt Felicitation Committee, Colombo, George Keyt Felicitation Committee, 1977, pp. 21-28.

Candappa, Reggie, Cedric de Silva, Sita de Silva, Arun Dias Bandaranaike, and Manilal Weerakoon, editors. George Keyt: A

Centennial Anthology, Colombo: George Keyt Foundation, 2001. Dissanayake, Ellen. "The Art of George Keyt and the Indian Raga."

George Keyt, edited by Ashley Halpe, Colombo, The George Keyt Felicitation Committee, 1977, pp. 41-43.

Goonasekera, Sunil. George Keyt Interpretations. Kandy, Institute of Fundamental Studies, 1991.

Goonetileke, H.A.I. "George Keyt: The Indian Ethos in a Ceylonese Studio." Arts of Asia, edited by Tuyet Nguyet, Hong Kong, Arts of Asia Publication, 1973, pp. 53-71.

---. “A Biographical Sketch.” George Keyt, edited by Ashley Halpe, Colombo, George Keyt Felicitation Committee, 1977, pp. 20-32.

Halpe, Ashley. "The Tortuous Path." George Keyt, edited by Ashley Halpe, Colombo, George Keyt Felicitation Committee, 1977, pp. 81-89.

Marasinghe, Walter. Bharatamuni Praṇita Nātyaśāstra. Nugegoda, Piyasiri Printing System, 1994.

Rangacharya, Adya. The Nātyaśāstra (English Translation with Critical

Notes). New Delhi, Munshiram Manoarlal Publisher Pvt Ltd., 1999.

Rodrigo, Nihal. "George Keyt and the Sri Lankan Tradition." George Keyt, edited by George Keyt Felicitation Committee, Colombo, George Keyt Foundation, 1997, pp. 51-59.

Russell, Martin. George Keyt (Introduction and Biographical Note).

Bombay, Phiroze K. Mistry for Marg Publication, 1950. 
The Influence of Indian Culture, Arts, and Aesthetics I Sudarshana Bandara

---. “George Keyt.” George Keyt, edited by Ashley Halpe. Colombo, George Keyt Felicitation Committee, 1977, pp. 2-8.

Schroeder, Ulrich Von. The Golden Age of Sculpture in Sri Lanka. Hong Kong, Visual Dharma Publication Ltd., 1992.

Lohuizen-De Leeuw, J. E. Van. Sri Lanka Ancient Arts. London, Commonwealth Institute, 1981. 